\title{
Effects of Resistance Training on Arterial Compliance and Plasma Endothelin-1 Levels in Healthy Men
}

\author{
K. TAGAWA ${ }^{1}$, S.-G. RA ${ }^{1}$, H. KUMAGAI ${ }^{2}$, T. YOSHIKAWA ${ }^{1}$, Y. YOSHIDA ${ }^{1}$, \\ K. TAKEKOSHI ${ }^{3}$, S. SAKAI ${ }^{3}$, T. MIYAUCHI ${ }^{3}$, S. MAEDA ${ }^{2}$ \\ ${ }^{1}$ Graduate School of Comprehensive Human Sciences, University of Tsukuba, Japan, ${ }^{2}$ Faculty of \\ Health and Sport Sciences, University of Tsukuba, Japan, ${ }^{3}$ Faculty of Medicine, University of \\ Tsukuba, Japan
}

Received November 29, 2017

Accepted April 13, 2018

\section{Summary}

Arterial compliance (AC) is an index of the elasticity of large arteries. Endothelial dysfunction has been reported to result in reduced arterial compliance, which represents increased arterial stiffness. A reduction in $\mathrm{AC}$ is elicited by high-intensity resistance training, however the mechanisms are obscure. Because a single bout of resistance exercise causes a transient increase in circulating plasma endothelin-1 in humans, some vasoconstrictors may play a role in the mechanisms. The present study aimed to investigate whether resistance training-induced decrease in $A C$ is associated with changes in circulating vasoconstrictors levels in young men. Young sedentary men were assigned to control $(n=5)$ or training $(n=9)$ groups. The training group performed four-week high-intensity resistance training (weight training exercise; three sessions/week). We measured AC and plasma levels of endothelin-1, angiotensin II, and norepinephrine before and after intervention. Resistance training significantly decreased $\mathrm{AC}$, whereas the changes in plasma levels of neither endothelin-1, nor angiotensin II, nor norepinephrine were significantly different between the control and the training groups. Moreover, we found no significant correlations between changes in circulating plasma levels (endothelin-1, angiotensin II, and norepinephrine) and in the AC. Despite of no alteration of the resting circulating plasma levels (endothelin-1, etc.), we cannot exclude a possibility that the tissue/local concentrations of vasoconstrictors (endothelin-1, etc.) around the vessels might be increased and also involved in a reduction of $\mathrm{AC}$ in the training group. Taken together, the present results suggest that circulating vasoconstrictors (endothelin-1, etc.) in plasma are not involved in a reduction in $\mathrm{AC}$ by the resistance training.

\section{Key words}

Resistance training $\bullet$ Carotid arterial compliance $\bullet$ Vasoconstrictor - Young men • Endothelin • EDCF

\section{Corresponding author}

S. Maeda, Division of Sports Medicine, Faculty of Health and Sport Science, University of Tsukuba, 1-1-1 Tennodai, Tsukuba, Ibaraki 305-8574, Japan. Fax: +81 29-853-2986. E-mail: maeda.seiji.gn@u.tsukuba.ac.jp

\section{Introduction}

Arterial compliance (AC) is an index of the elasticity of large arteries. It is used as an indicator of arterial stiffness. Endothelial dysfunction has been reported to result in reduced $\mathrm{AC}$, which represents increased arterial stiffness (Marti et al. 2012). Endothelin-1 (ET-1) is an endothelium-derived potent vasoconstrictive peptide with vasoproliferative activity (Barton and Yanagisawa 2008, Davenport et al. 2016, Houde et al. 2016, Miyauchi et al. 1990, Miyauchi and Goto 2013, Yanagisawa et al. 1988). Therefore, it is speculated that ET-1 released from vascular endothelium may be involved in alteration of $\mathrm{AC}$ in various physiological/pathophysiological conditions in humans. However, only few studies were reported concerning the alteration of AC and ET-1 in humans. Moreover, there is no report concerning the relations between alteration of $\mathrm{AC}$ and ET systems by resistance training in humans.

As for the alteration of $\mathrm{AC}$ and exercise/training, it has been reported that there is a differences between the 
aerobic exercise and the resistance exercise training (Collier et al. 2008). It was reported that aerobic exercise training increases $\mathrm{AC}$ in young normotensive subjects (Seals et al. 2003). The aerobic exercise training has also been shown to slow or lessen the progression of arterial stiffness associated with aging (Tanaka et al. 2000). On the contrary to the aerobic exercise, Collier et al. (2008) reported that resistance training decreases $\mathrm{AC}$ in the pre-hypertensive humans. Thus, there is a difference between the aerobic and the resistance training in the alteration of AC. On the other hands, Collier et al. (2008) also reported that the resistance training decreased significantly blood pressure (BP) to similar extent to that by the aerobic exercise in the pre-hypertensive humans, suggesting that both the resistance training and the aerobic exercise training are beneficial in lowering BP in the pre-hypertensive humans (Collier et al. 2008). Thus, the resistance exercise is recommended as a complement kinesiotherapy to an aerobic training kinesiotherapyprogram (Pescatello et al. 2004, Pollock et al. 2000) and offers many benefits for the aging population, including the prevention and treatment of hypertension, diabetes mellitus, metabolic syndrome, osteoporosis and sarcopenia (Eves and Plotnikoff 2006, Garber et al. 2011, Hurley and Roth 2000, Layne and Nelson 1999, Fielding 1995, Miller et al. 1994, Pollock et al. 2000, Williams et al. 2007). It has also been reported that the high-intensity resistance training decreases AC in healthy men (Miyachi et al. 2004, Miyachi 2013).

ET-1 is a potent vasoconstrictor peptide with vasoproliferative activity (Barton and Yanagisawa 2008, Davenport et al. 2016, Houde et al. 2016, Miyauchi et al. 1990, Miyauchi and Goto 2013, Yanagisawa et al. 1988). Generally, various effects of ET-1 are mediated via the ET type A receptor $\left(\mathrm{ET}_{\mathrm{A}}\right)$ and the $\mathrm{ET}$ type $\mathrm{B}$ receptor $\left(\mathrm{ET}_{\mathrm{B}}\right)$ which were the $\mathrm{G}$ protein-coupled receptors (Barton and Yanagisawa 2008, Davenport et al. 2016, Houde et al. 2016, Miyauchi and Goto 2013). Angiotensin II (Ang II) and norepinephrine (NE) also have a potent vasoconstrictive effect (Jiang et al. 2000, Miyauchi et al. 1990). We previously reported that the plasma ET-1 levels were increased in humans at various pathophysiological situations such as myocardial infarction (Miyauchi et al. 1989), renal failure (Miyauchi et al. 2012), and pulmonary hypertension (Ishikawa et al. 1995). We previously also demonstrated that an application of systemic $\mathrm{ET}_{\mathrm{A}} / \mathrm{ET}_{\mathrm{B}}$ receptor antagonists or systemic $\alpha$-adrenergic blockers increase $\mathrm{AC}$ in humans (Maeda et al. 2009, Sugawara et al. 2009). Moreover, a single bout of resistance exercise (concentric exercise) causes a transient increase in circulating ET-1 in humans (Okamoto et al. 2008). Thus, it is likely that these vasoconstrictors (ET-1, etc.) may contribute to decreasing $\mathrm{AC}$ caused by the resistance training. However, there is no report concerning the relation between alteration of $\mathrm{AC}$ and ET systems caused by resistance training in humans. Therefore, to answer this question, the present study aimed to investigate whether resistance traininginduced decrease in $\mathrm{AC}$ is associated with changes in circulating plasma vasoconstrictors levels (ET-1, Ang II, and NE) in young men.

\section{Methods}

\section{Subjects}

A total of 14 healthy men (age 21-35 years) were enrolled in a longitudinal study. They were assigned to the control $(\mathrm{n}=5)$ and training groups $(\mathrm{n}=9)$. All subjects were recruited from the local community through flyers, e-mails, and information sharing. None of the subjects had participated in any resistance or endurance training regularly. All subjects were non-smokers and cardiovascular disease-free and not taking cardiovascular medications. The subjects were instructed to maintain current eating behaviors for the duration of the intervention. The present study was conducted in accordance with the Declaration of Helsinki and was approved by the ethical committee of the University of Tsukuba (Tai 27-69: permitted on October 13, 2015). All subjects provided written informed consent.

\section{Experimental design}

We measured hemodynamics, muscle strength, AC, and plasma vasoconstrictors levels (ET-1, Ang II, and NE) before and after the intervention of the resistance training for four weeks in the exercise group. As the resistance training, the weight training exercise of the biceps curls were performed ( $75 \%$ of one-repetition maximum [1RM], 10 repetitions/set, five sets/session, three sessions/week) for four weeks in the exercise group in the present study. In the control group, we also measured hemodynamics, muscle strength, AC, and plasma vasoconstrictors levels (ET-1, Ang II, and NE) before and at the end of the four-week study.

\section{Measurements}

Before each test, subjects abstained from caffeine and fasted for at least $12 \mathrm{~h}$. All subjects were 
studied at least $48 \mathrm{~h}$ after they last exercised, to avoid acute effects of exercise. All measurements were performed at constant room temperature $\left(23-25^{\circ} \mathrm{C}\right)$, in a quiet room, after the subjects had rested in a supine position for at least $15 \mathrm{~min}$. The subjects were tested at the same time of the day throughout the study period to avoid potential diurnal variations.

\section{Strength testing}

The maximal muscular strength of all subjects was tested before and after intervention using biceps curls. All subjects performed warm up exercise, constituting 10 repetitions with $5 \mathrm{~kg}$ weights, and afterwards, 1RM was obtained based on the established guideline (Beachle et al. 2008). All repetitions of maximal strength test were performed in 3-s eccentric (lowering) and 3-s concentric (lifting) phases. Subjects repeated the actions at approximately constant velocities and frequencies with the aid of a metronome. The day-today coefficient of variation was $1.0 \pm 1.8 \%$ for $1 \mathrm{RM}$.

\section{$A C$ (indicator of arterial distensibility)}

Common carotid artery echography immediately after applanation of tonometrically obtained arterial pressure from the carotid artery permits noninvasive determination of dynamic AC. Common carotid artery diameter was measured using images derived from an ultrasound device (Logiq E; GE Healthcare, Tokyo, Japan) equipped with a high-resolution linear array transducer as previously described (Lage et al. 1993, Miyachi et al. 2004). A longitudinal image of the cephalic portion of the common carotid artery was acquired $1-2 \mathrm{~cm}$ distal to the carotid bulb. Computer images were analyzed using image analysis software (Image J, Maryland, USA). All image analyses were performed by the same investigator. The arterial lumen diameter at minimal diastolic relaxation and maximal systolic expansion was measured at three points per frame, with the points then being averaged. Carotid arterial pressure waveforms were obtained with arterial applanation tonometry using an array of 15 micropiezoresistive transducers (form PWV/ABI; Colin Medical Technology, Komaki, Japan) (Cortez-Cooper et al. 2003). These waveforms were calibrated by equating the mean arterial pressure and diastolic BP of the carotid to those of the brachial artery with each parameter being averaged over 10-15 continuous beats. Brachial BP was measured with the oscillometric method using the automated polygraph apparatus (form PWV/ABI; Colin
Medical Technology, Komaki, Japan). Heart rate was computed from ECG. The AC was calculated using the equation $[(\mathrm{D} 1-\mathrm{D} 0) / \mathrm{D} 0] /[2(\mathrm{P} 1-\mathrm{P} 0)] \pi(\mathrm{D} 0) 2]$, where $\mathrm{D} 1$ and $\mathrm{D} 0$ are the maximal and minimum diameters and $\mathrm{P} 1$ and $\mathrm{P} 0$ are the highest $\mathrm{BP}$ and lowest $\mathrm{BP}$, respectively (Miyachi et al. 2004). The daily coefficient of variation of AC was $6.8 \pm 2.7 \%$ in our laboratory.

Measurement of plasma vasoconstrictors (ET-1, Ang II, and NE) levels

Each blood sample was placed in a chilled tube containing EDTA $(2 \mathrm{mg} / \mathrm{ml})$ and then centrifuged at $3,000 \times g$ for $15 \mathrm{~min}$ at $4{ }^{\circ} \mathrm{C}$. The plasma samples were stored at $-80{ }^{\circ} \mathrm{C}$ until the assay. Plasma concentrations of ET-1 were measured by an enzyme-linked immunoassay kit (R\&D systems, Minnesota, USA). Plasma concentrations of Ang II were measured by an enzymelinked immunoassay kit (Enzo Life Sciences, New York, USA). The intra-assay coefficients of variation of ET-1 and Ang II were $7.5 \pm 7.1 \%$ and $2.6 \pm 2.4 \%$ in our laboratory, respectively. Plasma concentrations of $\mathrm{NE}$ were assayed by high-performance liquid chromatography (Tosoh Co, Tokyo, Japan). The intra-assay coefficient of variation of $\mathrm{NE}$ was $6.0 \pm 1.0 \%$, as previously described (NE, CA test TOSOH, Tosoh Co).

\section{Body composition}

Anthropometric measurements were taken with subjects' barefoot and wearing only light clothing. Height was measured to the nearest $0.1 \mathrm{~cm}$ using a stadiometer (AD-6227R, A\&D Co., Ltd., Tokyo, Japan). Body mass and body fat percentage were measured to the nearest $0.1 \mathrm{~kg}$ on a calibrated digital scale (InBody 770, InBody Japan, Tokyo, Japan) and adjusted for the estimated clothing mass by subtracting $0.5 \mathrm{~kg}$. Body mass index (BMI) was calculated as weight $/$ height $^{2}\left(\mathrm{~kg} / \mathrm{m}^{2}\right)$. Daily coefficients of variation for the two trials were $0.2 \pm 0.1 \%, 0.5 \pm 0.2 \%$, and $3.4 \pm 2.7 \%$ for body mass, BMI, and body fat percentage in our laboratory, respectively.

\section{Resistance training intervention}

Subjects in the training group performed the resistance exercise of the weight training exercise (biceps curls) three times per week throughout the 4-week study period. During training sessions, subjects performed biceps curls for five sets of 10 repetitions at $75 \%$ of 1RM with an inter-set rest period of 2 min (Okamoto et al. 2009a, Okamoto et al. 2015). We selected biceps curls 
because of their similarity to whole-body resistance training in terms of inducing an increase in arterial stiffness (i.e. decrease in AC) (Kawano et al. 2006, Miyachi et al. 2004, Okamoto et al. 2009a, Okamoto et al. 2015). The eccentric (lowering) and concentric (lifting) phases of all repetitions were each performed for $3 \mathrm{~s}$ (Okamoto et al. 2009a). The subjects repeated the actions at approximately constant velocities and frequencies with the aid of a metronome. Those who were able to complete 10 repetitions in the third set were given increased loads during subsequent exercise sessions. Each training session lasted for approximately $20 \mathrm{~min}$. The resistance exercise was performed until concentric failure, afterward remaining sets were completed with the support of assistants. Except for routine activities during training, all other exercises (resistance training and anaerobic and aerobic exercises) were prohibited.

\section{Statistical analysis}

All data were expressed as means \pm standard deviations of the mean unless otherwise indicated. The Shapiro-Wilk tests were used to evaluate the normal distribution. The unpaired sample t-tests or MannWhitney U-tests were used to examine significant differences in subject characteristics between the two groups (the control and training groups). A two-way analysis of variance with repeated measures was used to analyze hemodynamics, muscle strength, AC, and plasma levels of ET-1, Ang II, and NE. When a significant interaction was observed, the simple main effects of group or time were determined. Correlations between changes in the AC and in the plasma levels of ET-1, Ang II, or NE were assessed using Spearman's rank correlation coefficient $\left(r_{\mathrm{s}}\right)$ across all subjects. In all analyses, a two-tailed $P$ value of $<0.05$ was determined to be statistically significant. Statistical analyses were conducted using SPSS software version 24.0 for Windows (IBM SPSS Japan Inc., Japan).

\section{Results}

In the training group, all subjects completed every training session (three sessions/week for four weeks; i.e. a total of 12 training sessions during the four weeks). At the baseline just before starting the intervention (training), no significant differences were found in any of the parameters between the control and training groups such as body mass index, body fat (\%), plasma ET-1, plasma Ang II, plasma NE and the AC (Tables 1 and 2, Figs 1 and 2).

Before intervention, plasma levels of ET-1 in the training group tended to be higher than those in the control group. However, it was not statistically significant $(P=0.13)$. Moreover, before the intervention, plasma levels of NE in the training group also tended to be higher than those in the control group, however it was not statistically significance $(P=0.26)$. Thus, at the baseline levels just before starting the training, there were no significant differences in circulating plasma vasoconstrictor levels (ET-1, Ang II, and NE) between the control and training groups.

The interactions were significant on neither the BP nor the heart rate in between the control and training groups (Table 2); that is, neither the BP (systolic BP, mean BP, and diastolic BP) nor the heart rate changed at the end of the four-week study in the control group (Table 2), and neither the BP (systolic BP, mean BP, and diastolic BP) nor the heart rate changed at the end of the four-week study in the training group. On the other hands, we found significant interaction in the 1RM between the two groups $(F=42.61, P<0.05)$; that is, the

Table 1. Baseline characteristics of subjects.

\begin{tabular}{lccc}
\hline Variables & Control & Training & P-value \\
\hline Number of subjects & 5 & 9 & - \\
Age, years & $24 \pm 3$ & $25 \pm 4$ & 0.90 \\
Height, $\mathrm{cm}$ & $173 \pm 6$ & $174 \pm 7$ & 0.75 \\
Body mass, $\mathrm{kg}$ & $76.3 \pm 11.6$ & $69.3 \pm 13.6$ & 0.11 \\
Body mass index, $\mathrm{kg} \cdot \mathrm{m}^{-2}$ & $25.6 \pm 4.0$ & $23.0 \pm 4.4$ & 0.29 \\
Body fat, \% & $19.9 \pm 6.9$ & $20.3 \pm 9.4$ & 0.94 \\
\hline
\end{tabular}

Values are means \pm SD. 
Table 2. Changes in hemodynamics and muscle strength.

\begin{tabular}{|c|c|c|c|}
\hline \multirow{2}{*}{ Variables/Group } & \multicolumn{2}{|c|}{ Time-point } & \multirow{2}{*}{ Interaction } \\
\hline & Baseline & After intervention & \\
\hline \multicolumn{4}{|c|}{ Systolic BP, mm Hg } \\
\hline Control & $116 \pm 12$ & $115 \pm 8$ & $F=0.05$ \\
\hline Training & $122 \pm 6$ & $121 \pm 8$ & $P=0.83$ \\
\hline \multicolumn{4}{|l|}{ Mean $\mathrm{BP}, \mathrm{mm} \mathrm{Hg}$} \\
\hline Control & $83 \pm 9$ & $85 \pm 7$ & $F=0.31$ \\
\hline Training & $90 \pm 6$ & $91 \pm 7$ & $P=0.59$ \\
\hline \multicolumn{4}{|c|}{ Diastolic BP, $\mathrm{mm} \mathrm{Hg}$} \\
\hline Control & $65 \pm 7$ & $65 \pm 4$ & $F=0.04$ \\
\hline Training & $73 \pm 7$ & $73 \pm 4$ & $P=0.86$ \\
\hline \multicolumn{4}{|l|}{ Heart rate, bpm } \\
\hline Control & $55 \pm 3$ & $52 \pm 5$ & $F=1.58$ \\
\hline Training & $62 \pm 8$ & $62 \pm 5$ & $P=0.23$ \\
\hline \multicolumn{4}{|c|}{ 1RM biceps curls, $\mathrm{kg}$} \\
\hline Control & $23 \pm 3$ & $23 \pm 4$ & $F=42.61$ \\
\hline Training & $20 \pm 2$ & $23 \pm 2^{*}$ & $P<0.05$ \\
\hline
\end{tabular}

Values are means $\pm \mathrm{SD}$. BP, blood pressure; $1 \mathrm{RM}$, one repetition maximum. $* P<0.05$ vs. baseline. Control group: $\mathrm{n}=5$; Training group: $n=9$.

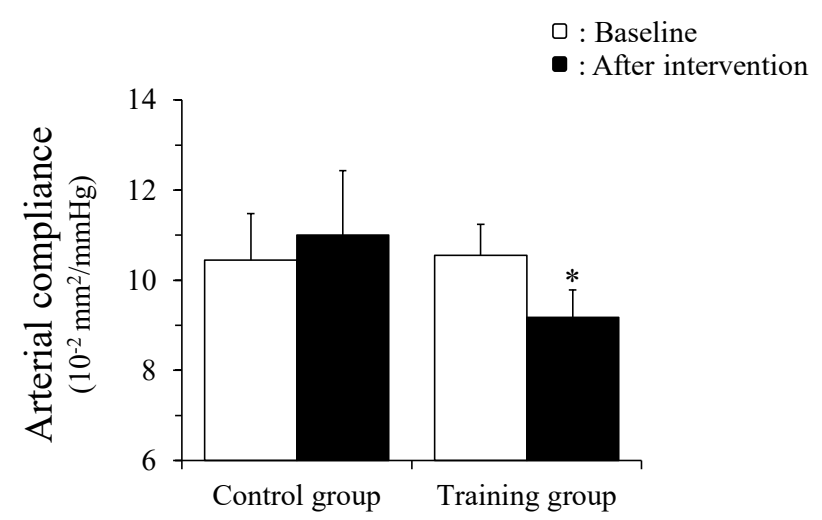

Fig. 1. The $A C$ before and after the four-week study in the control group $(n=5)$ and the training groups $(n=9)$. Two-way ANOVA reveals a significant interaction on AC. $* P<0.05$ : significant difference compared with the baseline in the training group using post-hoc analysis. Data are presented as mean $\pm \mathrm{SE}$. $\mathrm{AC}$, arterial compliance; ANOVA, analysis of variance.

$1 \mathrm{RM}$ was significantly increased after the intervention of the four-week training in the training group $(P<0.05)$, whereas the 1RM did not change at the end of the fourweek study in the control group (Table 2).

After the intervention, we found a significant interaction on changes in the $\mathrm{AC}$ between the groups using a two-way analysis of variance with repeated measures $\left[F_{(1,12)}=10.46, P<0.05\right]$ which was followed by post-hoc test. The post-hoc test showed that the AC of the training group was significantly decreased at the end of the four-week study (Fig. 1, from $10.6 \pm 2.1$ to $9.2 \pm 1.8$ $\left.10^{-2} \mathrm{~mm}^{2} / \mathrm{mm} \mathrm{Hg}, \quad P<0.05\right)$, whereas the AC of the control group did not change at the end of the four-week study (Fig. 1, from $10.5 \pm 2.3$ to $11.0 \pm 3.210^{-2} \mathrm{~mm}^{2}$ / $\mathrm{mm} \mathrm{Hg}, P=$ N.S. $)$.

Figure 2 shows the plasma vasoconstrictors (ET-1, Ang II, and NE) levels before and after the four-week study. The interactions of each value at the respective time-point (each value at Baseline, After intervention) and the groups (Control group, Training group) on the plasma vasoconstrictors (ET-1, Ang II, and NE) levels were not significant (ET-1: $F_{(1,12)}=0.83$, $P=$ N.S.; Ang II: $F_{(1,12)}=0.30$, $P=$ N.S.; NE: $F_{(1,12)}=1.03$, $P=\mathrm{N} . \mathrm{S}$.), that is, the plasma vasoconstrictors (ET-1, Ang II, and NE) levels did not change at the end of the four-week study in the training group and the plasma vasoconstrictors (ET-1, Ang II, and NE) levels did not change at the end of the four-week study in the control groups (Fig. 2).

The abscissa of the Figure 3 shows the changes of the plasma levels of ET-1 (upper), Ang II (middle), and NE (lower) before and after the four-week intervention in the control group and the training group. The ordinate of the Figure 3 shows the changes of the AC before and after the four-week intervention in the control 
group and the training group. We found no significant correlations between the changes (before and after the intervention) in plasma vasoconstrictors (ET-1, Ang II, and $\mathrm{NE}$ ) levels and the changes in the $\mathrm{AC}$ in the control group and the training group (ET-1: $r_{s}=0.29, P=0.32$; Ang II: $\quad r_{s}=-0.002, \quad P=0.99 ; \quad \mathrm{NE}: r_{s}=-0.25, \quad P=0.39$ ) (Fig. 3).
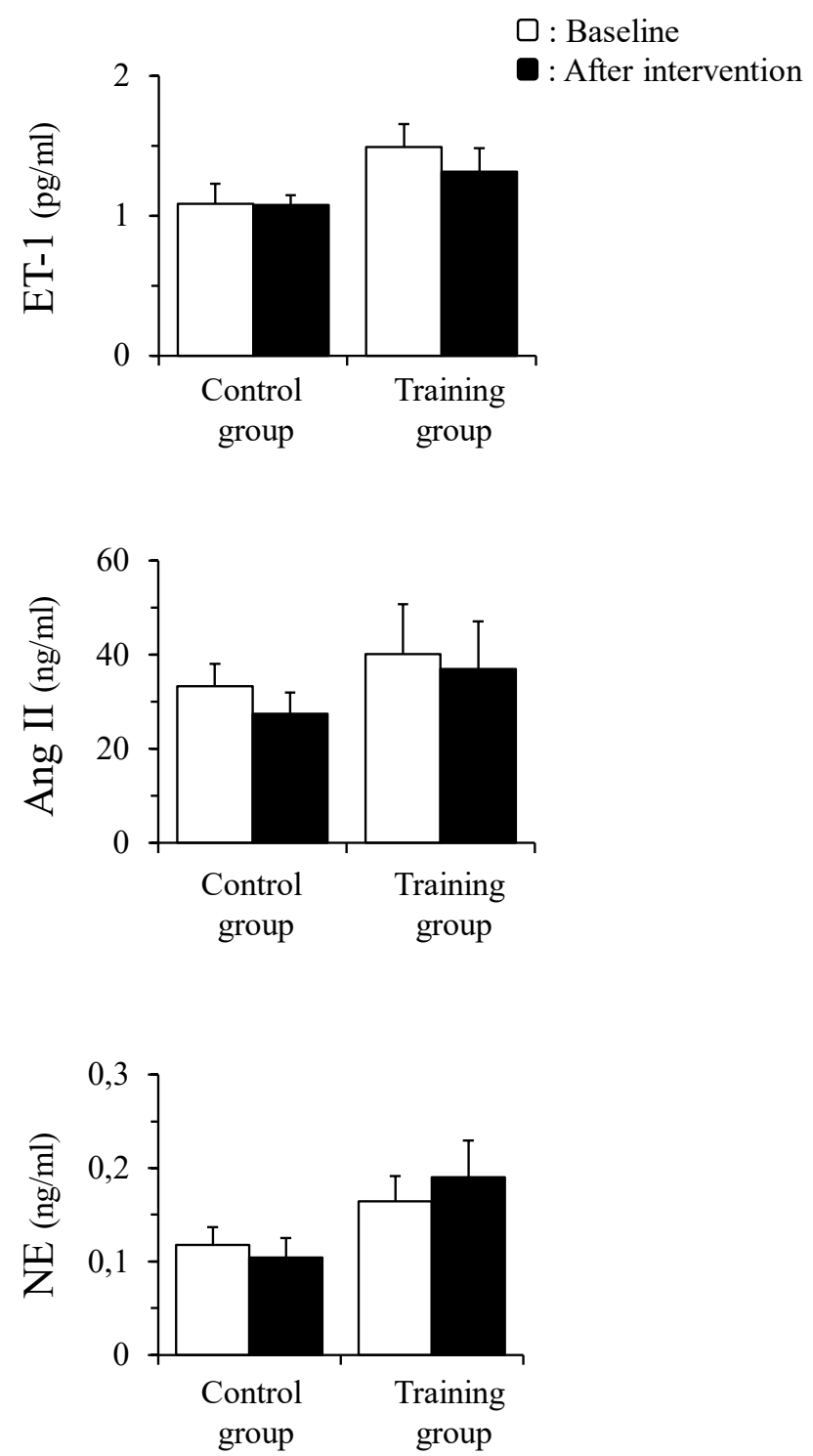

Fig. 2. The plasma vasoconstrictors (ET-1, Ang II, and NE) levels before and after the four-week study in the control group $(n=5)$ and the training group $(n=9)$. The interactions of each value at the respective time-point (each value at Baseline, After intervention) and the groups (Control group, Training group) on the plasma vasoconstrictors (ET-1, Ang II, and NE), determined using two-way ANOVA, were not significant; that is, the plasma vasoconstrictors (ET-1, Ang II, and NE) levels did not change at the end of the four-week study in the training group and also in the control groups. Data are presented as mean \pm SE. ET-1, endothelin-1; Ang II, angiotensin II; NE, norepinephrine; ANOVA, analysis of variance.

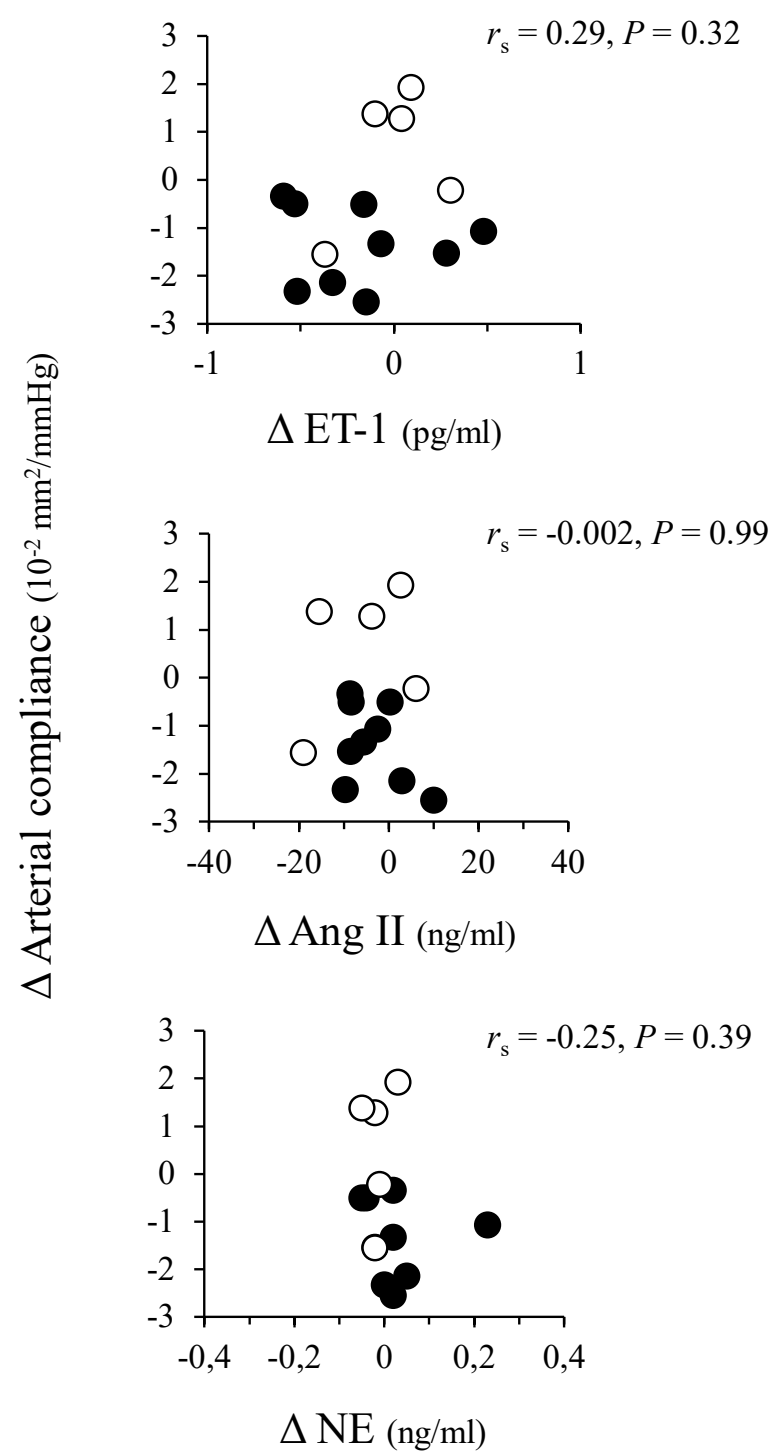

Fig. 3. The abscissa shows the changes of the plasma levels of ET-1 (upper), Ang II (middle), and NE (lower) before and after the four-week intervention in the control group $(n=5)$ and the training group $(n=9)$. The ordinate shows the changes of the AC before and after the four-week intervention in the control group and the training group. The correlations between the changes in the $A C$ and the changes in three types of plasma vasoconstrictors (ET-1, Ang II, and NE) levels before and after the intervention are shown in this Figure. There were no significant correlations between the changes in plasma vasoconstrictors (ET-1, Ang II, and NE) levels and the changes in the $\mathrm{AC}$ before and after the intervention assessed by the Spearman rank correlation coefficient analysis. The control $(O)$ and training $(\bullet)$ groups are shown. ET-1, endothelin-1; Ang II, angiotensin II; $\mathrm{NE}$, norepinephrine; $\mathrm{AC}$, arterial compliance.

\section{Discussion}

It has been reported that a single bout of resistance exercise (concentric exercise) caused a transient increase in circulating plasma ET-1 in humans (Okamoto et al. 2008). In the present study, the training group performed four-week resistance training (weight 
training exercise of biceps curls, three sessions/week). Therefore, it is thought that the repeated bout of the resistance exercise might cause a repeated increase in plasma ET-1 as well as a repeated increase in the tissue ET-1 around the vessels during the four-week intervention of the resistance training. In the present study, the resistance training in young men significantly decreased the AC (indicator of arterial distensibility), which was in accordance with previous reports concerning the resistance exercise training and the reduction in the AC (Collier et al. 2008, Miyachi et al. 2004, Miyachi 2013). The decrease in the AC represents an increase in the arterial stiffness. Because ET-1 has potent vasocontractile activity and vasoproliferative activity, it was possible that a repeated increase in the tissue ET-1 around the vessels in the training group might cause a repeated over-stimulation of the ET receptors $\left(\mathrm{ET}_{\mathrm{A}}\right.$ and $\left.\mathrm{ET}_{\mathrm{B}}\right)$ and hence might affect a vascular structure and might result in contributing to a decrease in $\mathrm{AC}$ in the training group of the present study.

The present study showed that the four-week resistance training in young men significantly decreased the $\mathrm{AC}$, whereas the resistance training did not change the basal circulating vasoconstrictors (ET-1, Ang II, and NE) levels. However, we cannot exclude a possibility that, at the basal condition after the four-week exercise training, the tissue/local ET-1 concentrations around the vessels may be increased and hence involved in a reduction of $\mathrm{AC}$ induced by the four-week resistance training. Indeed, there are several reports in which there is a difference between plasma and tissue ET-1 levels: the tissue ET-1 are elevated whereas the circulating plasma ET-1 levels are not changed in some conditions in the animal models of various diseases. In the deoxycorticosterone (DOCA)-salt hypertensive rats, the tissue ET-1 content of the thoracic aorta and mesenteric artery was significantly higher than that of the control normotensive rats, whereas the plasma ET-1 levels did not differ between the two groups (Wang et al. 2005). Therefore, similar to the case of the DOCA-salt hypertensive rats, it has a possibility that the tissue/local vascular-regulatory system by ET-1 may be enhanced in the training groups of our study, although the current resistance training did not change the resting circulating plasma levels of ET-1 in the young men. Taken together, the present results suggest that circulating plasma vasoconstrictors (ET-1, etc.) are not involved in a reduction in $\mathrm{AC}$ by the high-intensity resistance training.
As for the aerobic exercise and plasma ET-1, we previously reported that a single bout of aerobic exercise causes a transient increase of the plasma ET-1 levels in humans (Maeda et al. 1994, Maeda et al. 1997). It has been reported that a single bout of resistance exercise (concentric exercise) causes a transient increase in circulating plasma ET-1 in humans (Okamoto et al. 2008). Therefore, it is thought that, regardless of types of exercise (the aerobic exercise or the resistance exercise), a single bout of exercise causes a transient increase of the plasma ET-1 levels in humans. Moreover, using animal models of exercise, we previously reported that a single bout of exercise causes an organ-specific increase in ET-1 production in some organs such as the heart (Maeda et al. 1998a) and the kidney (Maeda et al. 1998b), but not the lung (Maeda et al. 1998a, Maeda et al. 1998b) in the rats. Therefore, it is considered that endogenous ET-1 may contribute to regulation of the cardiovascular systems under the exercise in both humans and animals.

A previous study has reported that circulating plasma ET-1 was increased about 1.4-fold immediately after a single bout of resistance exercise (Okamoto et al. 2008). We previously reported that high-intensity cycle ergometer exercise increased about 3-fold circulating plasma ET-1, and the increase remained until $60 \mathrm{~min}$ after exercise (Maeda et al. 1994, Maeda et al. 1997).

It has been reported that the stimulation of the ET receptors $\left(\mathrm{ET}_{\mathrm{A}}\right.$ and $\left.\mathrm{ET}_{\mathrm{B}}\right)$ causes an stimulation of the intracellular signal-transduction systems such as G protein, protein kinase C (PKC), Rho kinase, mitogenactivated protein kinase (MAP kinase) (Barton and Yanagisawa 2008, Davenport et al. 2016, Houde et al. 2016, Miyauchi and Goto 2013), therefore, it is possible that the ET receptors-intracellular signal-transduction systems may be changed after the four-week exercise training in the training groups; that is, it has a possibility that a repeated increase in the tissue ET-1 around the vessels by the resistance training during four weeks may cause a repeated over-stimulation of the vascular $\mathrm{ET}$ receptors $\left(\mathrm{ET}_{\mathrm{A}}\right.$ and $\left.\mathrm{ET}_{\mathrm{B}}\right)$ during the four weeks, therefore may result in an alteration of the ET receptors $\left(\mathrm{ET}_{\mathrm{A}}\right.$ and $\left.\mathrm{ET}_{\mathrm{B}}\right)$ - intracellular signal transduction systems (G protein, PKC, Rho kinase, MAP kinase, etc.) of the vascular smooth muscle cells in the young men with resistance training at the basal condition without changing the basal circulating plasma vasoconstrictors (ET-1, etc.) levels in the training group. Therefore, we cannot exclude a possibility that the four-week exercise might cause a change of the vascular ET receptors- 
intracellular signal transduction systems and hence might cause a decrease in the $\mathrm{AC}$ in the exercise group.

As for Ang II, there are also several reports in which there is a difference between circulating and tissue Ang II levels: the tissue Ang II levels are elevated whereas the circulating Ang II levels are not changed in some conditions in the animal models of various diseases. In spontaneously hypertensive rats (SHR) at the age of 14-week (typical hypertensive stage), the tissue Ang II content of the kidney was significantly higher than that of the age-matched Wistar-Kyoto rats, whereas the plasma Ang II levels did not differ between the two groups (Kobori et al. 2005). Therefore, similar to the case of the SHR rats, it has a possibility that the tissue/local vascular-regulatory system by Ang II may be enhanced in the training groups of our study, although the resistance training did not change the resting circulating plasma levels of Ang II in the young men.

It is well known that NE-release from the sympathetic nerve endings to the vessels is greatly increased during resistance exercise (Kraemer et al. 1999). In the present study, the subjects of the training group performed four-week resistance training (biceps curls, three sessions/week). Therefore, it is thought that the repeated bout of the resistance exercise might cause a repeated increase in the tissue NE around the vessels during four weeks. Because NE has vasoproliferative activity and vasocontractile activity via the $\alpha 1$ adrenalin receptors (Piascik and Perez 2001), it was speculated that a repeated increase in the tissue NE around the vessels in the training group during the four-week intervention might affect a vascular structure and this might contribute to a decrease in $\mathrm{AC}$ in the training group of the present study. On the other hand, the present data showed that the resting circulating plasma NE levels were not changed by the intervention of the four-week resistance training in the young men.

In general, the exercise training has different effects on the BP in the hypertensive and normotensive subjects; the exercise training causes BP decrease in the hypertensive subjects, whereas the exercise training does not cause BP decrease in the normotensive subjects, suggesting that baseline BP values affect BP changes elicited by exercise training. One meta-analysis demonstrated that the resistance training decreases systolic BP of pre-hypertensive humans, whereas it does not change that of normotensive humans (Cornelissen and Smart 2013). Collier et al. (2008) also reported that the resistance training decreased significantly BP to similar extent to that by the aerobic exercise in the pre-hypertensive humans. In the JNC-7 report (The Seventh Report of the Joint National Committee on Hypertension), the pre-hypertension has been defined as systolic BP of $120-139 \mathrm{~mm} \mathrm{Hg}$ or diastolic BP of $80-89 \mathrm{~mm} \mathrm{Hg}$, and the stage-1 hypertension has been defined as systolic BP of 140-159 mm Hg or diastolic BP of 90-99 mm Hg (Chobanian et al. 2003). In the above report by Collier et al. (2008), systolic BP and diastolic $\mathrm{BP}$ of the subjects are $136.4 \pm 3.4$ and $78.2 \pm 1.5$, respectively. On the other hand, the subjects of the present study were normotensive (systolic BP $122 \pm 6 \mathrm{~mm} \mathrm{Hg}$, diastolic BP $73 \pm 7 \mathrm{~mm} \mathrm{Hg}$ ), and the current exercise intervention did not change the level of the BP in the healthy men. Thus, it is possible that a difference in the baseline BP values by our study (normotensive subjects) and the Collier's study (pre-hypertensive subjects) may be a major reason for the difference in change in BP by resistance training. Our consideration is also consistent with the reports that highintensity resistance training does not change systolic BP in the normotensive humans (Miyachi et al. 2004, Okamoto et al. 2009b).

It has been reported that the circulating ET-1 is cleared mainly via the lung and the kidneys (De Nucci et al. 1989, Burkhardt et al. 2000, Staniloae et al. 2004, Langleben et al. 2006, Miyauchi and Goto 2013). Moreover, it has been reported that endogenous ET-1 is cleared via the endothelial $\mathrm{ET}_{\mathrm{B}}$ (Berthiaume et al. 2000, Burkhardt et al. 2000, Miyauchi and Goto 2013, Angus et al. 2017). When ET-1 is intravenously administered as a bolus, it disappears quite rapidly from the blood stream with a half-life of a few minutes (Miyauchi and Goto 2013). The lung appears to be one of the most important tissues for uptake, since approximately $60 \%$ of ET-1 is removed after a single passage through the pulmonary circulation (De Nucci et al. 1989, Burkhardt et al. 2000, Staniloae et al. 2004, Langleben et al. 2006, Miyauchi and Goto 2013). In the lung tissues, $\mathrm{ET}_{\mathrm{B}}$ is highly expressed and ET-1-ET $\mathrm{B}_{\mathrm{B}}$ complex may be taken up into cells through an internalization process and degraded by lysozomal enzymes, e.g. aspartic proteases (Berthiaume et al. 2000, Burkhardt et al. 2000, Miyauchi and Goto 2013, Angus et al. 2017). Neutral endopeptidase and lysozomal cathepsin $\mathrm{G}$ are also concerned with enzymatic degradation of ET-1 (Burkhardt et al. 2000, Miyauchi and Goto 2013). Thus, the circulating ET-1 level is considered to be determined by the balance between the synthesis of ET-1 by endothelium and the clearance by 
the organs (such as the lungs and the kidneys). We should point out that the ET-1 clearance studies in men have been limited, and that no clearance studies were performed in the present study. It has a possibility that the exercise intervention of the current study could alter the clearance of the circulating ET-1 in the healthy men. However, we did not measure this parameter and this might be a limitation of our study.

In the present study, we also have the following limitations. In the first, the sample power in the present study was 0.84 . Because it is considered that a power should be more than 0.80 and an $\alpha$ level should be less than 0.05 in the statistical evaluation for the differences (Cumming 2014), the present sample power (0.84) would meet this criteria and therefore it was considered that the present study would be in adequate sample size. Nevertheless, because the sample size of the present study was not large, larger sample size study will be needed to confirm our findings. Thus, it has a possibility that larger sample size study will result in the different conclusion form the current manuscript, and therefore, we write this possibility as a study limitation of current study. In the second, muscle strength may have improved with exercise intervention in the training group. However, muscle strength (evaluated by one repetition maximum) was not different from that of the control group after the intervention, so the muscle strength appears not to be different at the time when the plasma data were collected. This may invalidate any interpretation, and we consider this as a study limitation.

In conclusion, the present study showed that, in young men, the high-intensity resistance training of four-week periods caused a significant reduction of the $\mathrm{AC}$ (indicator of arterial distensibility) without changing the resting circulating vasoconstrictors (ET-1, Ang II, and $\mathrm{NE}$ ) levels. The decrease in the AC represents an increase in the arterial stiffness. Despite of no alteration of the resting circulating ET-1 levels, the present data cannot exclude a possibility that, at the basal condition after the four-week exercise training, the tissue/local ET-1 concentrations around the vessels may be increased and hence involved in a reduction of $\mathrm{AC}$ induced by the four-week resistance training without changing the resting circulating ET-1 levels in plasma. Moreover, because a single bout of resistance exercise (concentric exercise) causes a transient increase in circulating ET-1 in humans (Okamoto et al. 2008), it seems to be likely that a repeated increase in the tissue ET- 1 around the vessels in the present training group might cause a repeated over-stimulation of the ET receptors $\left(\mathrm{ET}_{\mathrm{A}}\right.$ and $\mathrm{ET}_{\mathrm{B}}$ ) during the four-week intervention and hence might affect a vascular structure and might result in contributing to a decrease in the $\mathrm{AC}$ in the training group via its strong vasoconstrictive/vasoproliferative actions of ET-1. Taken together, the present results suggest that circulating plasma vasoconstrictors (ET-1, etc.) are not involved in a reduction in the $\mathrm{AC}$ by the high-intensity resistance training in young men.

\section{Conflict of Interest}

There is no conflict of interest.

\section{Acknowledgements}

We would like to thank Ms. Yuriko Sawano and Mr. Kosaku Yamamoto for technical assistance.

The present study was supported by in part by a grant from Advanced Research Initiative for Human High Performance (ARIHHP) in the University of Tsukuba.

The current address of Dr. Song-Gyu Ra is Faculty of Sports and Health Science, Fukuoka University, Japan. The current address of Dr. Hiroshi Kumagai is Faculty of Health and Sports Science, Juntendo University, Japan.

\section{References}

ANGUS JA, HUGHES RJA, WRIGHT CE: Distortion of KB estimates of endothelin-1 $\mathrm{ET}_{\mathrm{A}}$ and $\mathrm{ET}_{\mathrm{B}}$ receptor antagonists in pulmonary arteries: possible role of an endothelin-1 clearance mechanism. Pharmacol Res Perspect 5: e00374, 2017.

BARTON M, YANAGISAWA M: Endothelin: 20 years from discovery to therapy. Can $J$ Physiol Pharmacol 86: 485-498, 2008.

BEACHLE TR, EARLE RW, WATHEN D: Resistance training. In: Essentials of Strength Training and Conditioning. 3rd ed., BEACHLE TR, EARLE RW (eds), Human Kinetics, Champaign, 2008, pp 381-412.

BERTHIAUME N, YANAGISAWA M, LABONTÉ J, D'ORLÉANS-JUSTE P: Heterozygous knock-out of ET(B) receptors induces BQ-123-sensitive hypertension in the mouse. Hypertension 36: 1002-1007, 2000. 
BURKHARDT M, BARTON M, SHAW SG: Receptor- and non-receptor-mediated clearance of big-endothelin and endothelin-1: differential effects of acute and chronic $\mathrm{ET}_{\mathrm{A}}$ receptor blockade. J Hypertens 18: 273-279, 2000.

CHOBANIAN AV, BAKRIS GL, BLACK HR, CUSHMAN WC, GREEN LA, IZZO JL JR, JONES DW, MATERSON BJ, OPARIL S, WRIGHT JT JR, ROCCELLA EJ; NATIONAL HEART, LUNG, AND BLOOD INSTITUTE JOINT NATIONAL COMMITTEE ON PREVENTION, DETECTION, EVALUATION, AND TREATMENT OF HIGH BLOOD PRESSURE; NATIONAL HIGH BLOOD PRESSURE EDUCATION PROGRAM COORDINATING COMMITTEE: The Seventh Report of the Joint National Committee on Prevention, Detection, Evaluation, and Treatment of High Blood Pressure: the JNC 7 report. JAMA 289: 2560-2572, 2003.

COLLIER SR, KANALEY JA, CARHART R JR, FRECHETTE V, TOBIN MM, HALL AK, LUCKENBAUGH AN, FERNHALL B: Effect of 4 weeks of aerobic or resistance exercise training on arterial stiffness, blood flow and blood pressure in pre- and stage-1 hypertensives. J Hum Hypertens 22: 678-686, 2008.

CORNELISSEN VA, SMART NA: Exercise training for blood pressure: a systematic review and meta-analysis. $J \mathrm{Am}$ Heart Assoc 2: e004473, 2013.

CORTEZ-COOPER MY, SUPAK JA, TANAKA H: A new device for automatic measurements of arterial stiffness and ankle-brachial index. Am J Cardiol 91: 1519-1522, 2003.

CORTEZ-COOPER MY, ANTON MM, DEVAN AE, NEIDRE DB, COOK JN, TANAKA H: The effects of strength training on central arterial compliance in middle-aged and older adults. Eur J Cardiovasc Prev Rehabil 15: 149-155, 2008.

CUMMING G: The new statistics: why and how. Psychol Sci 25: 7-29, 2014.

DAVENPORT AP, HYNDMAN KA, DHAUN N, SOUTHAN C, KOHAN DE, POLLOCK JS, POLLOCK DM, WEBB DJ, MAGUIRE JJ: Endothelin. Pharmacol Rev 68: 357-418, 2016.

DE NUCCI G, THOMAS R, D'ORLEANS-JUSTE P, ANTUNES E, WALDER C, WARNER TD, VANE JR: Pressor effects of circulating endothelin are limited by its removal in the pulmonary circulation and by the release of prostacyclin and endothelium-derived relaxing factor. Proc Natl Acad Sci U S A 85: 9797-9800, 1988.

EVES ND, PLOTNIKOFF RC: Resistance training and type 2 diabetes: considerations for implementation at the population level. Diabetes Care 29: 1933-1941, 2006.

FIELDING RA: The role of progressive resistance training and nutrition in the preservation of lean body mass in the elderly. J Am Coll Nutr 14: 587-594, 1995.

GARBER CE, BLISSMER B, DESCHENES MR, FRANKLIN BA, LAMONTE MJ, LEE IM, NIEMAN DC, SWAIN DP; AMERICAN COLLEGE OF SPORTS MEDICINE: American College of Sports Medicine position stand. Quantity and quality of exercise for developing and maintaining cardiorespiratory, musculoskeletal, and neuromotor fitness in apparently healthy adults: guidance for prescribing exercise. Med Sci Sports Exerc 43: 1334-1359, 2011.

HOUDE M, DESBIENS L, D'ORLÉANS-JUSTE P: Endothelin-1: biosynthesis, signaling and vasoreactivity. Adv Pharmacol 77: 143-175, 2016.

HURLEY BF, ROTH SM: Strength training in the elderly: effects on risk factors for age-related diseases. Sports Med 30: 249-268, 2000.

ISHIKAWA S, MIYAUCHI T, SAKAI S, USHINOHAMA H, SAGAWA K, FUSAZAKI N, KADO H, SUNAGAWA H, HONDA S, UENO H, YAMAGUCHI I, SUGISHITA H, GOTO K: Elevated levels of plasma endothelin-1 in young patients with pulmonary hypertension caused by congenital heart disease are decreased after successful surgical repair. $J$ Thorac Cardiovasc Surg 110: 271-273, 1995.

JIANG Y, TRIGGLE CR: Lack of involvement of endothelin-1 in angiotensin II-induced contraction of the isolated rat tail artery. Br J Pharmacol 131: 1055-1064, 2000.

KAWANO H, TANAKA H, MIYACHI M: Resistance training and arterial compliance: keeping the benefits while minimizing the stiffening. J Hypertens 24: 1753-1759, 2006.

KOBORI H, OZAWA Y, SUZAKI Y, NISHIYAMA A: Enhanced intrarenal angiotensinogen contributes to early renal injury in spontaneously hypertensive rats. J Am Soc Nephrol 16: 2073-2080, 2005.

KRAEMER WJ, FLECK SJ, MARESH CM, RATAMESS NA, GORDON SE, GOETZ KL, HARMAN EA, FRYKMAN PN, VOLEK JS, MAZZETTI SA, FRY AC, MARCHITELLI LJ, PATTON JF: Acute hormonal 
responses to a single bout of heavy resistance exercise in trained power lifters and untrained men. Can J Appl Physiol 24: 524-537, 1999.

LAGE SG, POLAK JF, O'LEARY DH, CREAGER MA: Relationship of arterial compliance to baroreflex function in hypertensive patients. Am J Physiol 265: H232-H237, 1993.

LANGLEBEN D, DUPUIS J, LANGLEBEN I, HIRSCH AM, BARON M, SENÉCAL JL, GIOVINAZZO M: Etiology-specific endothelin-1 clearance in human precapillary pulmonary hypertension. Chest 129: 689-695, 2006.

LAYNE JE, NELSON ME: The effects of progressive resistance training on bone density: a review. Med Sci Sports Exerc 31: 25-30, 1999.

MAEDA S, MIYAUCHI T, GOTO K, MATSUDA M: Alteration of plasma endothelin-1 by exercise at intensities lower and higher than ventilatory threshold. J Appl Physiol 77: 1399-1402, 1994.

MAEDA S, MIYAUCHI T, GOTO K, MATSUDA M: Differences in the change in the time course of plasma endothelin-1 and endothelin-3 levels after exercise in humans. The response to exercise of endothelin-3 is more rapid than that of endothelin-1. Life Sci 61: 419-425, 1997.

MAEDA S, MIYAUCHI T, SAKAI S, KOBAYASHI T, IEMITSU M, GOTO K, SUGISHITA Y, MATSUDA M: Prolonged exercise causes an increase in endothelin-1 production in the heart in rats. Am J Physiol 275: H2105-H2112, 1998a.

MAEDA S, MIYAUCHI T, KOBAYASHI T, GOTO K, MATSUDA M: Exercise causes tissue-specific enhancement of endothelin-1 mRNA expression in internal organs. J Appl Physiol 85: 425-431, 1998b.

MAEDA S, SUGAWARA J, YOSHIZAWA M, OTSUKI T, SHIMOJO N, JESMIN S, AJISAKA R, MIYAUCHI T, TANAKA H: Involvement of endothelin-1 in habitual exercise-induced increase in arterial compliance. Acta Physiol (Oxf) 196: 223-229, 2009.

MARTI CN, GHEORGHIADE M, KALOGEROPOULOS AP, GEORGIOPOULOU VV, QUYYUMI AA, BUTLER J: Endothelial dysfunction, arterial stiffness, and heart failure. J Am Coll Cardiol 60: 1455-1469, 2012.

MILLER JP, PRATLEY RE, GOLDBERG AP, GORDON P, RUBIN M, TREUTH MS, RYAN AS, HURLEY BF: Strength training increases insulin action in healthy 50- to 65-yr-old men. J Appl Physiol (1985) 77: 1122-1127, 1994.

MIYACHI M: Effects of resistance training on arterial stiffness: a meta-analysis. Br J Sports Med 47: 393-396, 2013.

MIYACHI M, KAWANO H, SUGAWARA J, TAKAHASHI K, HAYASHI K, YAMAZAKI K, TABATA I, TANAKA H: Unfavorable effects of resistance training on central arterial compliance: a randomized intervention study. Circulation 110: 2858-2863, 2004.

MIYAUCHI T, GOTO K: Cardiovascular peptides: endothelins. In: Handbook of Biologically Active Peptides - Second Edition. KASTIN AJ (ed.), Academic Press, Elsevier Inc., San Diego, 2013, pp 1402-1407.

MIYAUCHI T, YANAGISAWA M, TOMIZAWA T, SUGISHITA Y, SUZUKI N, FUJINO M, AJISAKA R, GOTO $\mathrm{K}$, MASAKI T: Increased plasma concentrations of endothelin-1 and big endothelin-1 in acute myocardial infarction. Lancet 2: 53-54, 1989.

MIYAUCHI T, TOMOBE Y, SHIBA R, ISHIKAWA T, YANAGISAWA M, KIMURA S, SUGISHITA Y, ITO I, GOTO K, MASAKI T: Involvement of endothelin in the regulation of human vascular tonus. Potent vasoconstrictor effect and existence in endothelial cells. Circulation 81: 1874-1880, 1990.

MIYAUCHI Y, SAKAI S, MAEDA S, SHIMOJO N, WATANABE S, HONMA S, KUGA K, AONUMA K, MIYAUCHI T: Increased plasma levels of big-endothelin-2 and big-endothelin-3 in patients with end-stage renal disease. Life Sci 91: 729-732, 2012.

OKAMOTO T, MASUHARA M, IKUTA K: Relationship between plasma endothelin-1 concentration and cardiovascular responses during high-intensity eccentric and concentric exercise. Clin Physiol Funct Imaging 28: 43-48, 2008.

OKAMOTO T, MASUHARA M, IKUTA K: Effects of muscle contraction timing during resistance training on vascular function. $J$ Hum Hypertens 23: 470-478, 2009a.

OKAMOTO T, MASUHARA M, IKUTA K: Upper but not lower limb resistance training increases arterial stiffness in humans. Eur J Appl Physiol 107: 127-134, 2009 b. 
OKAMOTO T, SAKAMAKI MS, MIN SK, YOSHIDA S, WATANABE Y, OGASAWARA R: Repeated cessation and resumption of resistance training attenuates increases in arterial stiffness. Int J Sports Med 36: 440-445, 2015.

PESCATELLO LS, FRANKLIN BA, FAGARD R, FARQUHAR WB, KELLEY GA, RAY CA; AMERICAN COLLEGE OF SPORTS MEDICINE: American College of Sports Medicine position stand. Exercise and hypertension. Med Sci Sports Exerc 36: 533-553, 2004.

PIASCIK MT, PEREZ DM: Alpha1-adrenergic receptors: new insights and directions. J Pharmacol Exp Ther 298: 403-410, 2001.

POLLOCK ML, FRANKLIN BA, BALADY GJ, CHAITMAN BL, FLEG JL, FLETCHER B, LIMACHER M, PIÑA IL, STEIN RA, WILLIAMS M, BAZZARRE T: AHA Science Advisory. Resistance exercise in individuals with and without cardiovascular disease: benefits, rationale, safety, and prescription: An advisory from the Committee on Exercise, Rehabilitation, and Prevention, Council on Clinical Cardiology, American Heart Association; Position paper endorsed by the American College of Sports Medicine. Circulation 101: 828-833, 2000.

SEALS DR: Habitual exercise and the age-associated decline in large artery compliance. Exerc Sport Sci Rev 31: 68-72, 2003.

STANILOAE C, DUPUIS J, WHITE M, GOSSELIN G, DYRDA I, BOIS M, CRÉPEAU J, BONAN R, CARON A, LAVOIE J: Reduced pulmonary clearance of endothelin in congestive heart failure: a marker of secondary pulmonary hypertension. J Card Fail 10: 427-432, 2004.

SUGAWARA J, KOMINE H, HAYASHI K, YOSHIZAWA M, OTSUKI T, SHIMOJO N, MIYAUCHI T, YOKOI T, MAEDA S, TANAKA $\mathrm{H}$ : Reduction in alpha-adrenergic receptor-mediated vascular tone contributes to improved arterial compliance with endurance training. Int J Cardiol 135: 346-352, 2009.

TANAKA H, DINENNO FA, MONAHAN KD, CLEVENGER CM, DESOUZA CA, SEALS DR: Aging, habitual exercise, and dynamic arterial compliance. Circulation 102: 1270-1275, 2000.

WANG H, CHEN AF, WATTS SW, GALLIGAN JJ, FINK GD: Endothelin in the splanchnic vascular bed of DOCA-salt hypertensive rats. Am J Physiol Heart Circ Physiol 288: H729-H736, 2005.

WILLIAMS MA, HASKELL WL, ADES PA, AMSTERDAM EA, BITTNER V, FRANKLIN BA, GULANICK M, LAING ST, STEWART KJ; AMERICAN HEART ASSOCIATION COUNCIL ON CLINICAL CARDIOLOGY; AMERICAN HEART ASSOCIATION COUNCIL ON NUTRITION, PHYSICAL ACTIVITY, AND METABOLISM: Resistance exercise in individuals with and without cardiovascular disease: 2007 update: a scientific statement from the American Heart Association Council on Clinical Cardiology and Council on Nutrition, Physical Activity, and Metabolism. Circulation 116: 572-584, 2007.

YANAGISAWA M, KURIHARA H, KIMURA S, TOMOBE Y, KOBAYASHI M, MITSUI Y, YAZAKI Y, GOTO K, MASAKI T: A novel potent vasoconstrictor peptide produced by vascular endothelial cells. Nature 332: 411-415, 1988. 